\title{
Entrepreneurial Development of "Ojek Sampah" (OJAH) through Android Applications
}

\author{
Yosua Damas Sadewo \\ Shanti Bhuana Institute, Bengkayang, 79214, Indonesia \\ Email: yosua.damas@shantibhuana.ac.id \\ Pebria Dheni Purnasari \\ Shanti Bhuana Institute, Bengkayang, 79214, Indonesia \\ Email: Pebria.dheni@shantibhuana.ac.id
}

Received: 05 December 2020; Accepted: 20 February 2021; Published: 08 August 2021

\begin{abstract}
The purpose of this research is to develop application-based "Ojah" entrepreneurship. This research will be conducted using the type of Research and Development. The entrepreneurship of the "Ojah" has been developed in an application that will become a medium for collecting waste. Data collection that will be used in this research is to use (1) Observation, which will be carried out for the maintenance of the development process and product testing (2) validation sheets, used as instruments in testing, and validation of the developed product (3) The questionnaire given to the public or users of the "Ojah" application to see the characteristics from the application used, a satisfaction questionnaire will also be used to measure the effectiveness of the resulting product (4) Field notes that are carried out simultaneously with the implementation of product trials that contain things that happened during the trial product; (5) Documentation that includes images or photographs during the research development being carried out. The results of the research show evidence that the development of the "Ojah" application. The results showed that the development of the android application-based garbage motorcycle taxi business showed measurable success through assessments conducted by several parties, including media experts, entrepreneurship experts, and users of android app-based "Ojah" services. Validation results by media experts and entrepreneurial experts showed that both businesses and applications developed to support The "Ojah" business are in a decent category. The validity score given by expert validators is 86.6 from entrepreneurial experts. In contrast, media experts provide an assessment of 84.24. Based on limited scale trials, the android-based "Ojah" application has characteristics that deserve to use in terms of practicality, use, service, and completeness, with a feasibility score of 77.35 .
\end{abstract}

Index Terms: Entrepreneurship Development, Garbage Ojek, Applications

\section{Introduction}

This research departed from the results of observations made by researchers in one of the environments in the Bengkayang sub-district, Bengkayang Regency, West Kalimantan Province. It is known that the results of observations found that the BTN Griya Bumi Sebalo Permai housing location does not yet have a garbage disposal container. The nearest garbage disposal storage bin is approximately $3 \mathrm{~km}$ from the BTN Griya Bumi Sebalo Permai housing location. As a result of the absence of a garbage disposal container, local people have to collect and dispose of their garbage. The relatively far distance to the location of the garbage disposal bin also makes local people reluctant to throw garbage where it should be. Because of this, trash is often found scattered on the streets and around the BTN Griya Bumi Sebalo Permai location. Littering is a form of environmental pollution. This is expressed by [1] Aazam all, that the accumulation of garbage can have a negative impact on the environment if the trash is not collected in time. Subekti [2] also expressed a similar opinion that the accumulation of waste is increasing from year to year because there are no adequate facilities and infrastructure that impact environmental pollution. Garbage is no longer used, unused, and disliked or is thrown away and comes from human activities and cannot happen by itself [3]. Therefore, simple countermeasures such as disposing of garbage in its place are simple solutions to protect against environmental pollution.

Humans in their various activities almost always produce waste or garbage because disposable items are no longer needed after use, so the next choice is none other than throwing away these items. Based on its nature, waste is classified into two types, namely organic waste and inorganic waste [4]. Organic waste is biodegradable and is 
composed of organic compounds so that it is easily decomposed or quickly broken down, for example, food scraps, leather, and wood. Meanwhile, inorganic waste is non-degradable and is composed of inorganic compounds making it difficult to decompose, for example, plastics, bottles, and metals [5]. Garbage, when it accumulates and is left just like that, it will cause a liquid to smell bad. In addition, the inorganic waste that is allowed to pile up will also make the environment look very dirty. This, of course, will significantly disturb the comfort of the environment. If this continues, it will be a big problem and impact environmental damage [6].

However, in reality, the waste management carried out by the government and the community is not optimal, so there is still garbage accumulation in places that should not be [7]. Therefore, proper waste management efforts are needed so that environmental problems caused by waste can be overcome. "Waste management covers all the activities necessary for monitoring the waste generated in a city, from its beginning, when citizens produce their waste, through the collection, transportation, and arrival at its final accommodation, which can be the landfill, incineration, or recycling [8]. This is as expressed by [9] Suryani; it is necessary to build a culture of healthy living by disposing of garbage in its place to keep the environment clean. The first step that the community can take is to dispose of waste in its place. By disposing of the trash in its proper place, the garbage will not be scattered everywhere. Besides that, the waste can be transported to a landfill that has been provided by the government. Therefore, ideas emerged from the nation's children to create a service that can help overcome this problem, for example, there are online garbage taxis, waste banks, and others. These services are made to answer community needs, for example, people who live far from landfills and have difficulty disposing of rubbish, as happened at BTN Griya Bumi Sebalo Permai, Bengkayang District, Bengkayang Regency.

Based on these things, the "Ojah" service is here to make it easier for people to dispose of waste without the hassle of throwing it away in a remote place. "Ojah" appears as a form of creativity and innovation in entrepreneurship. The ability of innovation and creativity is absolutely essential for entrepreneurs to have and possess, with this ability, in general, an entrepreneur will be able to create a new product and be able to maintain the outcome [10]. Besides, with the advancement of technology, entrepreneurial activities can be linked to the application of technology as a form of innovation in facing global competition [11]. Seeing this phenomenon, in Bengkayang Regency, West Kalimantan province, there is no service business engaged in the transportation of waste. Bengkayang is a district directly adjacent to the state of Malaysia. Conditions in the Bengkayang district are not as advanced as in other cities, so Bengkayang is also called the disadvantaged, frontier, and outermost region in Indonesia. As a district located in the border area, Bengkayang must move quickly to leave behind to become a developed district. Bengkayang itself has a large area and a reasonably busy population. If seen from the large population, Bengkayang needs at least one service provider, such as an "Ojah". This can undoubtedly be an opportunity to start an application-based waste "ojek" business. These opportunities are also based on the results of a survey that was conducted in Bengkayang. Based on the survey results that have been described above, it can be concluded that in Bengkayang, especially at BTN Griya Sebalo Permai, people find it difficult to dispose of garbage because the distance to the garbage disposal facility is quite far. They also have to dispose of their waste because there is no garbage collection service. Surveys or observations are carried out using the method of observation and interviews with the surrounding community so that the data obtained is in accordance with the actual conditions. From the explanation and explanation above, entrepreneurial waste "ojek" will be created and carried out in Bengkayang to be a solution and existing problems. Based on the background described above, the formulation of the problem is as follows:

(1) What are the results of the application-based "Ojah" entrepreneurship development?

(2) What are the characteristics of application-based "Ojah" entrepreneurship development?

Following the formulation problem, the research objectives are as follows :

(1) To find out the results of the application-based waste "ojek" entrepreneurship development

(2) To determine the characteristics of application-based waste "ojek" entrepreneurship development

\section{Methodology}

This research is categorized in research and development, namely developing waste motorcycle taxi applications to support entrepreneurial activities in services. The development model used in this research is the development model from Borg and Gall [12]. The Borg and Gall development model consists of 10 steps which are then grouped into three main steps to facilitate research. The development steps in this research include preliminary studies, product development, and product validation, and product testing.

In the preliminary study, the steps taken were collecting and analyzing information about the problems and needs required for waste collection, assessing and formulating the importance of the waste collection, reviewing the theory that is the basis for development, and examining the characteristics of previous "Ojah". Besides, at this stage, identifying the aspects of society in terms of technology use is also carried out, as well as material analysis, namely identifying, detailing, and systematically drafting the concept. This is done for material organization, display, and 
application use. After this step is carried out, the next stage is to design the supporting components. Activities undertaken in designing the model components include designing product designs and designing the impact of using the "Ojah" application. At this stage, the design of an "Ojah" application is aimed at producing a material prototype in the application regarding an "Ojah".

The product development stage prepared a draft product design that was developed, namely the "Ojah" application. Before being tested, the draft product is reviewed whether the adequacy of the supporting product theories has been fulfilled properly for each product component so that it is ready to be tested for its validity by experts and practitioners from a theoretical rational point of view and consistency of its construction. At this stage, prototype 1 is produced as an integrated part of the prototype 1 model, namely the realization of the results of the required "Ojah" application design. Then the trial was carried out and after the results of the field trials were obtained and the data analysis of the results of the trials were revised. This trial and revision can be carried out repeatedly until the desired prototype model ("Ojah" application) is obtained based on aspects of practicality and effectiveness.

In the stage of product validation, expert validation activities assess the feasibility and validity of the developed Ojah application. Validation activities are carried out to assess the feasibility and validity of the "Ojah" application being developed. The validation results are used to revise the "Ojah" application and show the feasibility of the "Ojah" application to be used in the community of residents of BTN Perum Griya Sebalo Permai, Bengkayang District. The activities carried out when doing model validation are as follows. 1) asking for expert and practitioner considerations regarding the feasibility of the "Ojah" application. This activity requires an instrument in the form of a validation sheet that is submitted to the validator. 2) analyze the validation results of the validator. If the results of the analysis show: a) valid without revision, then the next activity is field trials. b) valid with a few revisions, then the next activity is to revise first, then direct field trials. c) invalid, then a revision is made to obtain a new prototype. Then return to the activity of asking for expert and practitioner consideration or the validation stage. After obtaining a valid product, the "Ojah" application developed is ready to be tested.

The focus of research in this development research is to produce the "Ojah" application product that is effective and has practical characteristics that the community can easily use.

Data sources were obtained from all research and development activities carried out by developing the "Ojah" application by adding organic waste recycling.

In this research, the techniques used for data collection were: (1) Observations were made to observe the development process and product testing (2) validation sheets, used as instruments in testing, and validation of the products developed (3) The questionnaire given To the public or users of the "Ojah" application to find out the characteristics of the application used, a satisfaction questionnaire will also be used to measure the effectiveness of the resulting product (4) Field notes that are carried out simultaneously with the implementation of product trials that contain things that happened during the trial try the product; (5) Documentation which includes pictures or photos during the ongoing research and development conducted.

Data analysis techniques to be used in this study include validity tests and product efficiency tests. The validity test conducted consists of 2 stages, namely the questionnaire sheet's validity test to measure the product's efficiency by the user and the product validity test conducted by media experts and entrepreneurial experts to see the feasibility of the product, namely the android-based Ojah application. Measurement of product efficiency by analyzing questionnaires distributed to users to measure the android-based Ojah business's usefulness. The value and category of product feasibility refer to Table 1 .

Table 1. Value and Feasibility of Product Validation

\begin{tabular}{|l|l|}
\hline Score Interval & Category \\
\hline $75,00<\mathrm{x} \leq 100,00$ & Very worthy \\
\hline $50,00<\mathrm{x} \leq 75,00$ & Well worth it \\
\hline $25,00<\mathrm{x} \leq 50,00$ & Not feasible \\
\hline $0,00<\mathrm{x} \leq 25,00$ & Very unworthy \\
\hline
\end{tabular}

Table 1 shows that the development product is feasible to use because the average value is $\geq 50$. The user's score of product efficiency shows that Ojah's business development is also viable, and the score is $\geq 50$. These results show that the development of Ojah entrepreneurial activities supported by android applications is in a decent category.

\section{Results}

\section{A. Product Development Results}

The "Ojah" ("Ojah") application is made through the JDK (Java Development Kit) software than through the Integrated Development Environment (IDE) Android studio. The making of the "Ojah" application is based on the designed flowchart and storyboard. The "Ojah" application is made as much as possible to make it easier for users to order trash collection easily. Seeing from the average community in the BTN Griya Bumi Sebalo Permai housing using the WhatsApp application, the order feature via WhatsApp is made in the "Ojah" application. In addition, it makes it 
easier for the public to download the "Ojah" application through the yosada.id website, which of course, is supported for use on Android. The following is an overview of the appearance of the smartphone as a result of the "Ojah" application that has been made.

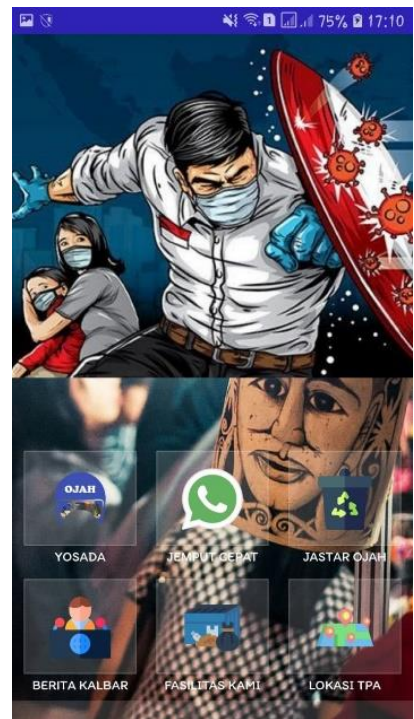

Fig. 1. "Ojah" Application display that have been installed on a smartphone (slide 1)

Figure 1 shows the screen view of the Ojah app that has been installed on Android. There are several features in the Ojah application. In developing this feature, consider the needs of entrepreneurs to be accepted and used by Ojah services users. Figure 2 shows the components contained in the Ojah service in detail.
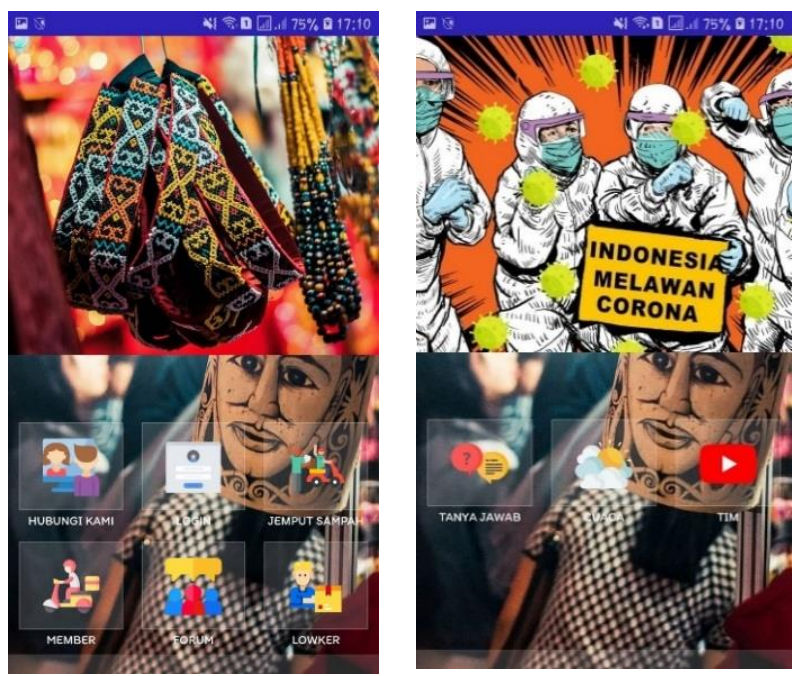

Fig. 2. "Ojah" Application display that has been installed on a smartphone (slide 2)

Figure 2 shows the screenshot view on Android of the installed Ojah app. This section offers various features and services that users can access to facilitate the use of Ojah services. Besides, in the Ojah application display, multiple images can give users a moral message who access this application. Ojah app can be installed by download this app through the official website of Ojah under the service name "Jastar" application. The spread of the application itself is done through social media, namely by sharing the link of Ojah's service website and promotional activities to one of the target sites of this application trial. The appearance of the Ojah application from the website is as follows. 


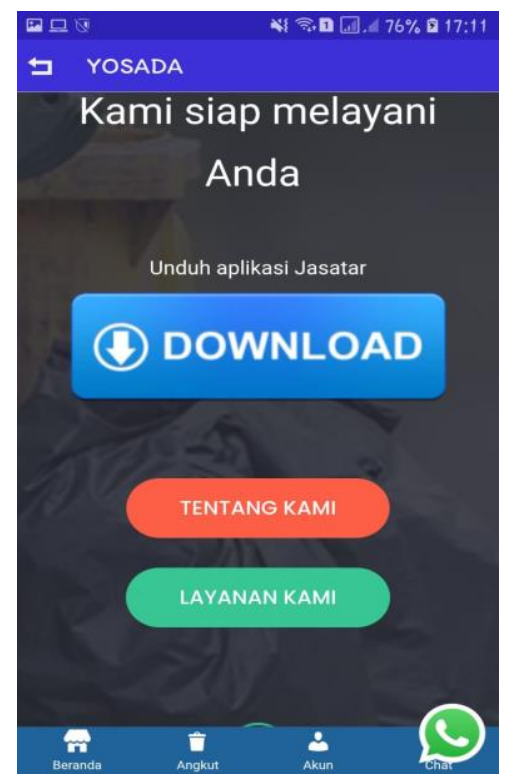

Fig. 3. "Ojah" Application display that have been installed on a smartphone (slide 3)

Downloaded and installed applications by users are then used to order Ojah services. At this stage, the socialization of product download and installation is carried out. The next stage is the trial stage with the user.

The results of the trial of the "Ojah" (garbage "oojek") application that have been made are known to be running and can be used and can be done to order garbage pick-up "Ojah" application trials are carried out for approximately 1 month with 3 users as test users of the "Ojah" application. The results of the application trial for approximately 1 month were known to have no problems, the 3 users also said that the application can be used and it is very easy to order trash pick-up.

\section{B. Product Characteristics}

Entrepreneurship development of application-based "Ojah" is one of the efforts made in generating entrepreneurial activities in Bengkayang, considering that there is no entrepreneurship in this field. In addition, the development of application-based "Ojah" entrepreneurship aims to help the community, specifically in the BTN Bumi Griya Sebalo Permai area, in transporting and disposing of garbage in the space provided. To make it easier for the "Ojah" service, a unique application was made, namely the "Ojah" application. This is done considering that many people are familiar with the use of Android. The characteristics of the "Ojah" are seen based on product feasibility and product effectiveness. Product feasibility is assessed from the validation of entrepreneurial actors and media experts. To see the product's effectiveness, a product assessment is carried out from the community as users of the "Ojah" application.

\section{(1) Entrepreneurs Validation/ Experts}

The validation of the "Ojah" application was carried out by several actors or experts in the field of entrepreneurship to measure the validity of the product from an entrepreneurial point of view, considering that the "Ojah" application was made as a form of entrepreneurial development in the Bengkayang area. The linkage between the "Ojah" application and the development of entrepreneurial activities is that it begins with the community's need to dispose of garbage in its place. Based on these needs, to provide convenience and efficiency in terms of waste disposal, then developed a garbage motorcycle taxi business based on android applications. Ojah service is the development of entrepreneurial activities in services with the theme of practicality and efficiency. Three entrepreneurial experts ' feasibility test is conducted to measure whether the android application-based garbage motorcycle taxi business developed is feasible and qualified for entrepreneurship.

The expert validators selected were two lecturers in the Entrepreneurship Study Program and one entrepreneur. The following is an assessment of the feasibility of the "Ojah" application by entrepreneurial experts. The assessment aspects are classified into four aspects, namely (1) practical aspects; (2) entrepreneurial aspects; (3) aspects of innovation; (4) aspects of creativity; (5) aspects of usability. Here's an assessment of the feasibility of garbage motorcycle taxi applications by entrepreneurial experts. 
Table 2. Validation of "Ojah" Applications by Entrepreneurial Experts

\begin{tabular}{|c|c|c|c|c|c|c|c|}
\hline No & Code & (1) & (2) & (3) & (4) & (5) & Average \\
\hline 1 & RSW_1 & 80 & 90 & 90 & 90 & 95 & 89 \\
\hline 2 & RSW_2 & 70 & 95 & 82 & 88 & 88 & 84.6 \\
\hline 3 & RSW_3 & 78 & 90 & 85 & 85 & 85 & 86.2 \\
\hline \multicolumn{8}{|c|}{ Average Score } \\
\hline
\end{tabular}

Based on Table 2, it is known that the average product feasibility value is 86.6. This value is in the very decent category. According to entrepreneurial experts who become validators in assessing the feasibility of developed businesses has an excellent opportunity. Entrepreneurial activities developed have practicality, innovation, creativity, usefulness, and business opportunities designed to have good potential. Entrepreneurs see that the "Ojah" application can be a special business opportunity in the Bengkayang area, considering that business in the field of waste disposal services is still not yet entrenched, so application-based waste "ojek" entrepreneurs provide innovations in the Bengkayang area. If you look closely, all assessed aspects get a score of $\geq 70$, where the score is in the feasible category. There are some suggestions given, including the practicality of the application. There needs to be an increase in application installation because there are still some obstacles. Based on the calculation of the validation value above, it can be seen that the average score for each aspect is described as follows.

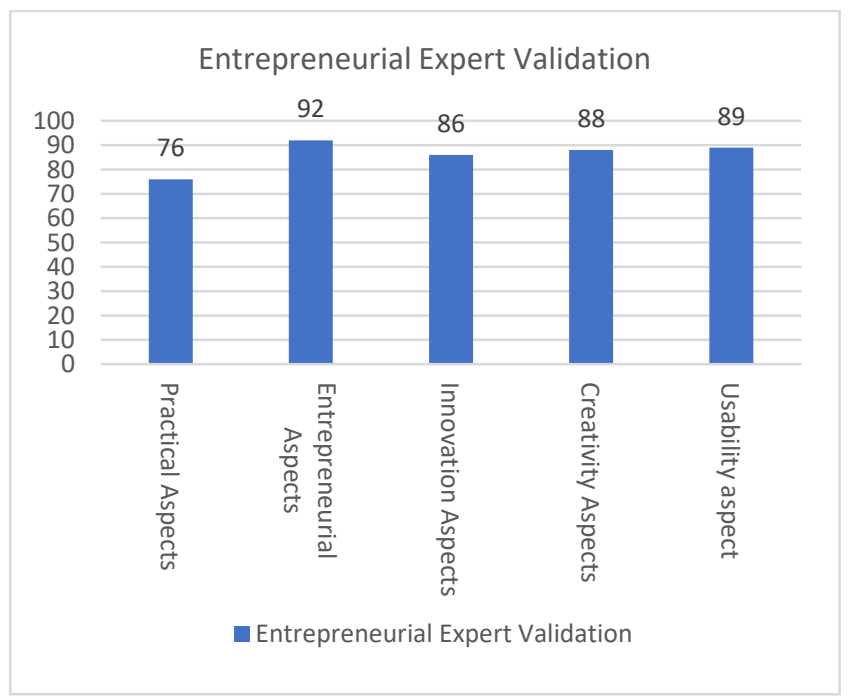

Fig.4. Average validation value of entrepreneurial experts

Based on Table 2, it is known that the average product feasibility value is 86.6. This value is in the very decent category. According to entrepreneurial experts who become validators in assessing the feasibility of developed businesses has an excellent opportunity. Entrepreneurial activities developed have practicality, innovation, creativity, and have usefulness, and business opportunities designed have good potential

(2) Media Expert Validation

Media experts also carry out validation to see whether the "Ojah" application can be used and has a low error rate so as to minimize access failure or application usage. The aspects that become indicators of assessment are practical aspects (1), display aspects (2), feature aspects (3), and usage aspects (4). The following describes the results of the analysis from the media expert validation test.

Table 3. Validation of "Ojah" Applications by Media Experts

\begin{tabular}{|c|c|c|c|c|c|c|}
\hline No & Code & $(\mathbf{1})$ & $(\mathbf{2})$ & $\mathbf{( 3 )}$ & $\mathbf{( 4 )}$ & Average \\
\hline 1 & RSM_1 & 85.33 & 87.5 & 91.5 & 76.67 & 85.25 \\
\hline 2 & RSM_2 & 82.67 & 83.5 & 90 & 78.33 & 83.63 \\
\hline 3 & RSM_3 & 82.33 & 83 & 90 & 80 & 83.83 \\
\hline \multicolumn{7}{|c|}{ Average Score } \\
\hline
\end{tabular}

The media expert validator's assessment calculation shows that technically the android-based Ojah application used to support the business offers a decent result with an average score of 84.24. This result indicates that the android-based Ojah application developed can operate adequately. This result also shows that the application developed is feasible to 
use and can support Ojah's business activities. Ojah application that the media validator has tested is said to have good characteristics, based on Ojah application's assessment, has a low error rate. However, access is still limited, i.e., only compatible in some devices only.

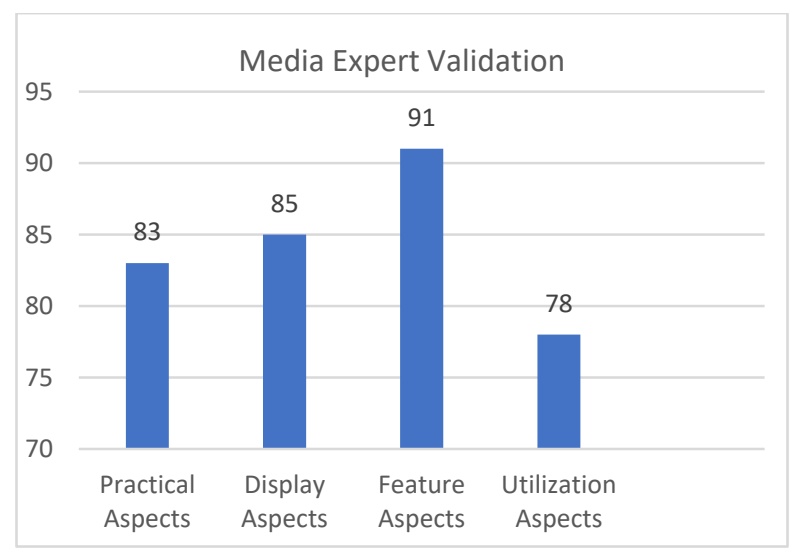

Fig. 5. Average Validation Value of Media Expert

Figure 5 shows the calculated results of the average values in each aspect. Based on the diagram presented in Figure 5, it can be known that the assessment of the android-based Ojah application is in the range of 78 to 91 , this result shows that the "Ojah" application is in the feasible category. This is in accordance with the conclusions given by media experts, but there need to be improvements in several aspects to avoid application access failure.

(3) Community Assessment

After the validation is done, the next step is to test the product on a small scale. The application users are selected based on location, namely in the BTN Change Griya Bumi Sebalo Permai area, with ten people. Product trials are carried out in approximately one month, in which users or consumers of "Ojah" services make transactions with the "Ojah" application. After the user uses the "Ojah" service through the application within the specified period, a product evaluation is carried out by asking the user to provide an assessment. The ratings given by users are shown in Table 4.

Table 4. Assessment of the Android-Based "Ojah" Application by users

\begin{tabular}{|c|c|c|c|c|c|c|}
\hline No & Code & $(\mathbf{1})$ & $(\mathbf{2})$ & $\mathbf{( 3 )}$ & $\mathbf{( 4 )}$ & Average \\
\hline 1 & RSP_1 & 73.33 & 88.33 & 91.67 & 63.33 & 79.17 \\
\hline 2 & RSP_2 & 66.66 & 80 & 86.67 & 59.33 & 73.17 \\
\hline 3 & RSP_3 & 89.33 & 81.67 & 90 & 61.67 & 80.67 \\
\hline 4 & RSP_4 & 82.33 & 84.33 & 87.67 & 56.67 & 77.75 \\
\hline 5 & RSP_5 & 83.33 & 78.33 & 82. & 57.33 & 75.42 \\
\hline 6 & RSP_6 & 74.33 & 84.33 & 90 & 63.33 & 78.00 \\
\hline 7 & RSP_7 & 75 & 75 & 87 & 63.33 & 75.08 \\
\hline 8 & RSP_8 & 84.33 & 86 & 86 & 63.33 & 79.92 \\
\hline 9 & RSP_9 & 75 & 85 & 87.33 & 58.33 & 76.42 \\
\hline 10 & RSP_10 & 81 & 86.67 & 87.33 & 56.67 & 77.92 \\
\hline
\end{tabular}

Community assessment after using android application-based Ojah showed a good response. The average value given by the user who is the respondent is in the category is very decent. This result indicates that respondents representing the community in one environment can be accepted using Android application-based Ojah. The four aspects assessed are practical aspects (1), usage aspects (2), service aspects (3), completeness aspects (4). Although on average, the assessment given gives good results, if viewed in detail each aspect, it can be known that there is one aspect that gets a less full review, namely completeness.

At this point, it is known that users cannot make payments online while ordering services are made online. This will be used as evaluation material to improve the completeness aspects of the developed "Ojah" application. The calculation of the assessment results of the "Ojah" application by users is shown in the following figure. But that doesn't mean the users can't use the android app-based Ojah service. Therefore, the measurement is done to see if the product developed is an Android-based Ojah service designed can be accessed and used by the public. 


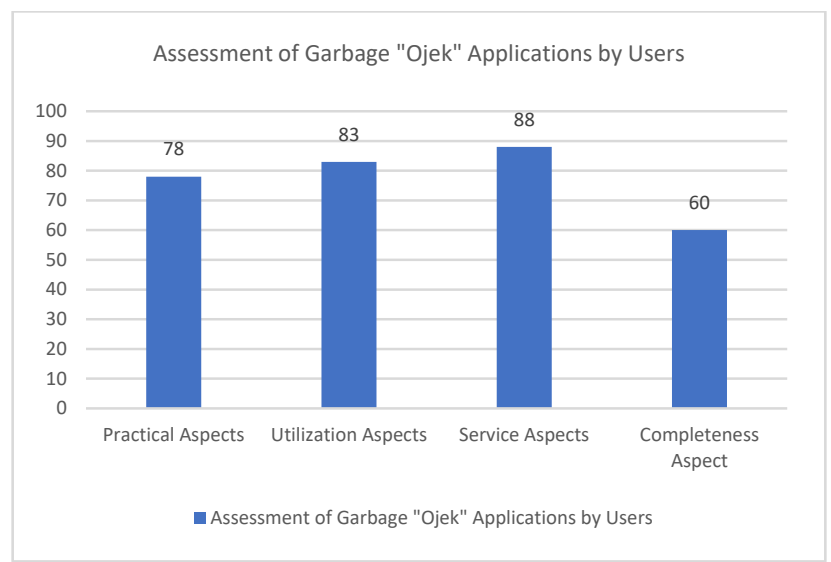

Fig.6. Average Aspects Value of "Ojah" Application by User

Based on the calculated average value, it can be seen that the application-based "Ojah" service received a fairly good response by users. Where on the aspects of practicality, use, and service scores in the good category. As for the completeness aspect, it scores in the sufficient category. Broadly speaking, the trash ojek application that has been tested can be run by users without any problems, but there are still some deficiencies in the application that can be improved.

\section{Discussion}

The development of application-based "Ojah" entrepreneurial activities shows that the application can be operated properly. "Ojah" services have undergone changes where previously they were done conventionally but with technological developments, it can be developed through applications. The use of the "Ojah" application in fact has received a good response from the community as users. It is known that based on the results of good validation carried out by entrepreneurial experts and media experts, it is known that the "Ojah" application can be used for the limited scale trial phase. The validation value shows that the "Ojah" application is in the suitable category for use. One of the entrepreneurial expert validators stated that the "Ojah" business was not familiar to the Bengkayang community, with this business, it was hoped that it could create jobs for people in the Bengakayang area and provide insight into the culture of disposing of garbage in its place. The target of an application-based "ojek" business is to provide waste collection and disposal services to make it easy for the community and instill a culture of not littering anywhere. "Ojah" services developed through applications have a focus on easiness in communicating anytime and anywhere to make it easier for "Ojah" users.

The results of the assessment of "Ojah" users show a positive response in which the application made can be accepted and used with minimal constraints, besides that the level of user satisfaction shown through the service aspect is in the high category with a value of 88.This indicates that the "Ojah" application has achieved the target, namely providing the "Ojah" service that can be accepted by the community and get a positive response. The assessment given by the community at the same time shows that the characteristics of the "Ojah" application are in the category of easy access, practical, and satisfying service. These results prove the success of a limited-scale trial in the BTN area of Griya Bumi Sebalo Permai Housing. To be used on a broad scale, it is necessary to make improvements based on the evaluation results of the limited scale test. The application-based "Ojah" entrepreneurship development results can certainly trigger other entrepreneurs to always see the opportunities that exist and maximize these opportunities creatively and innovatively [13]. The development of entrepreneurship based on "Ojah" that has been carried out indicates the use of technology to answer challenges in global competition, where entrepreneurs are required to have creativity and innovation. As expressed by Maryati, with increasingly fierce global competition, entrepreneurs are required to have high creativity, including being able to do business and compete with their competencies [11]. Erickson et al. [14] suggest with an entrepreneurship program can prepare the students to have experience. The use of technology in entrepreneurship also has its own added value for young entrepreneurs, this is in line with the opinion of Fitirati et al. which state that the skills can be sharpened through an entrepreneurship program-based technology where it can inspire other businesses actors [15]. A similar result was also shown by Teja et al. [16] that the development of application-based garbage can create a better living environment and preserve the cleanliness level in the city. The development of an application-based "Ojah" application is a new breakthrough in entrepreneurship, specifically in the Bengkayang region. Besides that, it can inspire other business actors to continue developing, especially in a situation of increasingly tighter global competition and increasingly advanced technological developments. 


\section{Conclusion}

On the results of the data analysis that has been done, it is known that the results of the study showed the development of an android-based Ojah application was successfully carried out and can also be applied to support the business of garbage motorcycle taxi services (Ojah). The products developed are in a suitable category based on the validator test of media experts and entrepreneurs. The development of an android-based Ojah application to support waste shuttle business activities can be used by the public but still on a limited scale. Expert validators' validity score is 86.6 from entrepreneurial experts, while media experts assess 84.24. Based on this limited scale trial, it is known that the android-based Ojah application has characteristics that deserve to be used both in terms of practicality, use, service, and completeness, with a feasibility score of 77.35. The results show that the Ojah application development is one form of innovation in assistance with technological developments, namely the android application-based Ojah business. This result indicates that business activities do not have to sell products but can also be in services. The growth of the application-based Ojah business received a positive response from the community. The convenience offered through android-based applications allows users to use this service easily. Users of OJAH services based on android applications feel helped in the garbage disposal while reducing the habit of dumping waste in any place so that this business can minimize environmental pollution with the Ojah app.

\section{Acknowledgment}

Thanks, are given to the Shanti Bhuana Institute for fund this research activity from the beginning till finished.

\section{References}

[1] M. Aazam, Ioannis, "Cloud-based Smart Waste Management for Smart Cities," IEEE 21st International Workshop, pp. 188-193 Oct. 2016.

[2] S. Subekti, "Pengelolaan Sampah Rumah Tangga 3R Berbasis Masyarakat," Semarang, 2010.

[3] B. Chandra, Pengantar kesehatan lingkungan, Jakarta: Penerbit buku kedokteran EGC, 2007.

[4] K. Sejati, Edisi Kelima. Pengolahan Sampah Terpadu dengan Sistem Node, Sub Point dan Center Point., Yogyakarta: Penerbit Kanisius, 2009.

[5] S. Mukrimah, "Efektivitas Biodegradasi Sampah Buah dengan Penambahan Bioaktivator Kotoran Sapi," Universitas Islam Indonesia, 2018.

[6] R. Setyowati and S. A. Mulasari, "Pengetahuan dan Perilaku Ibu Rumah Tangga dalam Pengelolaan Sampah Plastik," Jurnal Kesehatan Masyarakat Nasional, vol. 12, no. 7, pp. 562-566, 2013.

[7] Riswan, H. R. Sunoko and A. Hadiyanto, "Pengelolaan Sampah Rumah Tangga di Kecamatan Daha Selatan," Jurnal Ilmu Lingkungan, vol. 9, no. 1, pp. 31-38, 2011.

[8] K. Pardini, J. J. P. C. Rodrigues, O. Diallo, A. K. Das, C. H. C. de Albuquerque, and S. A. Kozlov. A Smart Wate Management Solution Geared towards Citizens. Sensors Journal, vol. 20, no. 8, pp. 1-15. 2020.

[9] S. Suryani, "Peran Bank Sampah dalam Efektivitas Pengelolaan Sampah (Studi Kasus Bank Sampah Malang)," Jurnal Aspirasi, vol. 5, no. 1, pp. 71-84, 2014.

[10] Y. D. Sadewo, P. D. Purnasari and B. G. Dimmera, Pendidikan Kewirausahaan Berbasis Ketahanan Nasional dan Budaya Amare, Bengkayang: PT. Tohar Media, 2019.

[11] W. Maryati, "Peran Perguruan Tinggi dalam Pemberdayaan Enterpreneurship untuk Mengembangkan Wirausaha Kecil Menghadapi Persaingan Global," Jombang, 2012.

[12] W. R. \&. G. M. D. Borg, Educational Research: an Introduction (7. ed), New York: Logman Inc, 2003.

[13] Y. D. Sadewo, P. D. Purnasari and B. G. Dimmera, "Development of Entrepreneurship Education Teaching Material Based on the National Resilience and Amare Culture," Journal of Education, Teaching and Learning 5.1 , pp. 41-45, 2020.

[14] S. M. Erickson and W. Laing. The Oxford MBA: A Case Study In Connecting Academia with Business. Journal of Entrepreneurship Education, vol. 19, no. 1, pp. 1-8. 2016.

[15] R. Fitriati and T. Hermiati " Entrepreneurial Skills and Characteristics Analysis on the Graduates of the Department of Administrative Sciences, FISIP Universitas Indonesia" Journal of Administrative Sciences \& Organization, vol. 17, no. 3, pp. 262-275.

[16] P. S. Teja, M. M. Krishna and V. R. Kolluru "Development of IOT based Garbage Management System using NodeMCU," International Journal of Engineering and Advanced Technology, vol. 8, no. 4, pp. 1549-1556, 2019. 


\section{Authors' Profiles}

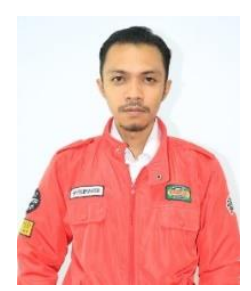

Yosua Damas Sadewo is a lecturer in the entrepreneurship study program at the Shanti Bhuana Institute. He is a graduate and Master of Education Management at Kristen Satya Wacana University, Salatiga. Graduated as an undergraduate elementary school teacher education in 2012 and graduated as a master of education management in 2015. He has been actively working as a teaching staff since 2016 until now at the Shanti Bhuana Institute located in Bengkayang Regency, West Kalimantan.

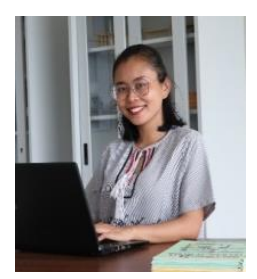

Pebria Dheni Purnasari is a lecturer in the Shanti Bhuana Institute's primary school teacher education study program. She graduated with a Bachelor of Elementary Teacher Education at Kristen Satya Wacana University, Salatiga and a Masters in Elementary Teacher Education at Semarang State University. Graduated as an undergraduate primary school teacher education in 2012 and graduated with a master's degree in primary school teacher education in 2018. She has been actively working as a teaching staff since 2018 until now at the Shanti Bhuana Institute located in Bengkayang Regency, West Kalimantan.

How to cite this paper: Yosua Damas Sadewo, Pebria Dheni Purnasari, " Entrepreneurial Development of "Ojek Sampah" (OJAH) through Android Applications", International Journal of Information Engineering and Electronic Business(IJIEEB), Vol.13, No.4, pp. 20-29, 2021. DOI: 10.5815/ijieeb.2021.04.02 